\title{
Inclusion of Dietary Palm Oil and Soy Oil on Growth Performance and Nutrition Digestibility in Broiler Chickens
}

\author{
Vetriselvi Sampath ${ }^{1}$, Jae Hong Park ${ }^{2}$ and In Ho $\mathrm{Kim}^{2+}$ \\ ${ }^{I}$ Student, Department of Animal Resource \& Science, Dankook University, Cheonan 31116, Republic of Korea \\ ${ }^{2}$ Professor, Department of Animal Resource \& Science, Dankook University, Cheonan 31116, Republic of Korea
}

\begin{abstract}
The effects of palm oil and soy oil supplementation in broiler chickens on growth performance and nutrient digestibility of dry matter, nitrogen, and energy was evaluated. In this experiment, 702 one-day-old Ross 308 cross bred chicks with an initial body weight of $42.23 \pm 0.05 \mathrm{~g}$ (mean $\pm \mathrm{SD})$ were utilized in a completely randomized treatment design (13 replicates/treatment, 18 chickens/cage) and fed for 35 days with CON (basal diet), T1 (Basal diet $+1.3 \%$ palm oil), and T2 (Basal diet $+1.3 \%$ soy oil). From days 1 to 7 , the body weight gain (BWG), feed intake (FI), and feed conversion ratio (FCR) were not significantly affected by the supplementation with palm oil or soy oil. However, from days 7 to 21 , BWG showed a tendency to increase compared to that with the control treatment. Moreover, BWG was significantly improved $(P<0.05)$ with palm and soy oil supplementation during the overall experiment in comparison to that with the control diet. In addition, the palm oil-supplemented group had higher BWG than the soy oil treatment group $(P<0.05)$. During the overall experiment, FI tended to increase in the T1 group compared to that in the other groups. There was no significant effect on FCR and nutrient digestibility of dry matter, nitrogen, and energy during the overall trial with the supplementation of palm or soy oil. In summary, the inclusion of dietary palm and soy oil has a beneficial effect on the growth performance of broiler chickens.

(Key words: growth performance, nutrient digestibility, palm oil, soy oil, broiler)
\end{abstract}

\section{INTRODUCTION}

Chicken meat is commonly consumed around the world because they are rich in protein and lower in fat. Energy is the foremost dietary component for the high performance of animals. With a high energy density, fats and oils have become more important energy sources in poultry feed composition. Thus, chicken requires a diet with high nutritional and energy density to enhance their growth performance. During the 21st century, the cost of poultry feed meets approximately $60 \sim 70 \%$ of the total production cost (Wilson and Bayer, 2000), however, energy alone contributes almost $70 \%$ of the feed cost (Saleh et al., 2004). In order to minimize feed cost, poultry producers are showing their interest to use the cheapest form of energy source that promotes the growth rate.

In the past decades, grains and cereals were replaced with highly concentrated energy sources like fats and oils in poultry diet. Oils or fats are the main source of monounsaturated fatty acid (MUFA) and polyunsaturated (PUFA) fatty acid in the diet (De Sousa Lima et al., 2016). Such oils or fats are very essential not only for humans but also for animals. Fats supplementation in diet recognized as a valuable method for meeting high energy requirements of rapid growth in broilers. Vegetable oils are highly digestible and considered as the best source of energy for livestock. Palm oil is one of the most abundant and generally used as vegetable oil worldwide (Murugesan et al., 2013; Ayisi et al., 2017). It contains adequate amounts of $\beta$-carotene, tocopherols and tocotrienols, $50 \%$ saturated fatty acids, $40 \%$ MUFA and $10 \%$ PUFA and these natural antioxidants provides high energy density in the diet (Babalola et al., 2011). Previously, Smink et al. (2008) reported that use of palm oil in broiler had a positive influence on meat firmness. Moreover, Soy oil is a high-quality of edible oil for humans and high-quality of vegetable protein in animal feed worldwide. It contains 61\% (PUFA) and 24\% (MUFA) and rich in sterols, vitamin A, E and K. Ayed et al. (2015) stated that using soy oil and palm oil in poultry feed would subsequently affect human health in a positive manner.

\footnotetext{
${ }^{+}$To whom correspondence should be addressed : inhokim@dankook.ac.kr
} 
Moreover, Kamran et al., (2020) reported that supplementation of soy oil had higher performance than other sources in growing broiler. In addition, Blanch et al. (1996) and Zhao and Kim (2017) reported that soy oil and palm oil had enhance the growth performance in broiler chickens. However, Soybean meal, wheat bran, and tallow are significantly contributed as dietary fat sources, although the limited use of these sources does not suggest that they are less important to the poultry industry. To our knowledge, there is limited information presented on the use of palm oil and $1.3 \%$ soy oil in poultry diet Therefore, the objective of this study was carried out to find the effect of palm oil and soy oil on growth performance and nutrient digestibility of dry matter, nitrogen and energy in broiler chickens.

\section{MATERIALS AND METHODS}

The experiment was performed under protocols approved by the Animal Care and Use Committee of Dankook University, Cheonan, Republic of Korea, for animal experimentation (Approval no DK-1-1930).

\section{Experimental Diet and Birds Housing}

A total of seven hundred and two 1-d old Ross 308 broiler chicks (mixed-gender) with an initial weight of $42.23 \pm 0.05 \mathrm{~g}$ (mean $\pm \mathrm{SD}$ ) were used in 35 days growth assay. chickens were randomly distributed (13 replicates/treatment, 18 chickens/cage) into three treatment groups and fed with the following diet: CON (basal diet), TRT 1 (Basal diet $+1.3 \%$ palm oil), TRT 2 (Basal Diet $+1.3 \%$ soy oil). Initially, birds were raised in $33 \pm 1^{\circ} \mathrm{C}$ temperature later it was reduced up to $24^{\circ} \mathrm{C}$ and the humidity was maintained around $60 \%$ for the remaining trials. During the trial chickens were housed using the stainless-steel cages of the same size $(1.75 \times 1.55 \mathrm{~m})$ and had free access to feed and water. The basal diets were formulated to meet or exceed the dietary requirements of broilers during starter (d 1 21) and finisher (d 22 35) phase, according to NRC (1994) recommendations. Experimental diet ingredients and chemical compositions were shown in Table 1 and 2 .

\section{Sampling and Measurement}

Table 1. Chemical composition of experimental diets (as fed-basis)

\begin{tabular}{|c|c|c|c|}
\hline \multirow{2}{*}{ Item } & \multicolumn{3}{|c|}{ Starter ${ }^{1}$} \\
\hline & Control & Palm oil & Soy oil \\
\hline \multicolumn{4}{|l|}{ Ingredients $(\%)$} \\
\hline Corn & 50.61 & 48.90 & 48.61 \\
\hline Soybean meal & 37.04 & 36.50 & 36.38 \\
\hline Corn gluten meal & 4.50 & 6.76 & 7.16 \\
\hline Wheat bran & 3.00 & 3.00 & 3.00 \\
\hline Soybean oil & - & - & 1.30 \\
\hline Tallow & 1.30 & - & - \\
\hline Palm kenel oil & - & 1.30 & - \\
\hline Tricalcium phosphate & 1.95 & 1.94 & 1.94 \\
\hline Limestone & 0.84 & 0.84 & 0.84 \\
\hline Salt & 0.36 & 0.36 & 0.36 \\
\hline DL-Methionine (98\%) & 0.19 & 0.19 & 0.19 \\
\hline L-Lysine (98\%) & 0.01 & 0.01 & 0.02 \\
\hline Mineral $\operatorname{mix}^{2}$ & 0.10 & 0.10 & 0.10 \\
\hline Vitamin $\operatorname{mix}^{3}$ & 0.10 & 0.10 & 0.10 \\
\hline Total & 100.00 & 100.00 & 100.00 \\
\hline \multicolumn{4}{|l|}{ Chemical composition } \\
\hline $\mathrm{ME}(\mathrm{kcal} / \mathrm{kg})$ & 3200 & 3200 & 3200 \\
\hline Crude protein (\%) & 23.00 & 23.00 & 23.00 \\
\hline Ether extract $(\%)$ & 3.89 & 3.94 & 3.94 \\
\hline Crude fibre $(\%)$ & 3.18 & 3.28 & 3.30 \\
\hline Ash (\%) & 6.57 & 6.63 & 6.63 \\
\hline $\mathrm{Ca}(\%)$ & 1.10 & 1.10 & 1.10 \\
\hline Available P (\%) & 0.57 & 0.57 & 0.57 \\
\hline Lysine (\%) & 1.26 & 1.26 & 1.26 \\
\hline Methionine (\%) & 0.54 & 0.54 & 0.54 \\
\hline
\end{tabular}

${ }^{1}$ Starter diet provided during d 1 to 21 .

${ }^{2}$ Provided per kg of complete diet: $37.5 \mathrm{mg} \mathrm{Zn}$ (as $\mathrm{ZnSO}_{4}$ ); 37.5 mg Mn (as $\left.\mathrm{MnO}_{2}\right) ; 37.5 \mathrm{mg} \mathrm{Fe}\left(\right.$ as $\left.\mathrm{FeSO}_{4} \cdot 7 \mathrm{H}_{2} \mathrm{O}\right) ; 3.75 \mathrm{mg} \mathrm{Cu}$ (as $\mathrm{CuSO}_{4} \cdot 5 \mathrm{H}_{2} \mathrm{O}$ ); $0.83 \mathrm{mg} \mathrm{I}$ (as $\mathrm{KI}$ ); and $0.23 \mathrm{mg} \mathrm{Se}$ (as $\mathrm{Na}_{2} \mathrm{SeO}_{3} \cdot 5 \mathrm{H}_{2} \mathrm{O}$ ).

${ }^{3}$ Provided per kg of complete diet: 15,000 IU of vitamin A, 3,750 IU of vitamin $\mathrm{D}_{3}, 37.5 \mathrm{IU}$ of vitamin $\mathrm{E}, 2.55 \mathrm{mg}$ of vitamin $\mathrm{K}_{3}$, $3 \mathrm{mg}$ of thiamin, $7.5 \mathrm{mg}$ of rivoflavin, $4.5 \mathrm{mg}$ of vitamin $\mathrm{B}_{6}$, $24 \mathrm{ug}$ of vitamin $\mathrm{B}_{12}, 51 \mathrm{mg}$ of niacin, $1.5 \mathrm{mg}$ of folic acid, 0.2 $\mathrm{mg}$ of biotin and $13.5 \mathrm{mg}$ of Ca-pantothenate. 
Table 2. Chemical composition of experimental diets (as fed-basis)

\begin{tabular}{|c|c|c|c|}
\hline \multirow{2}{*}{ Item } & \multicolumn{3}{|c|}{ Finisher $^{1}$} \\
\hline & Control & Palm oil & Soy oil \\
\hline \multicolumn{4}{|l|}{ Ingredients (\%) } \\
\hline Corn & 54.45 & 53.41 & 53.33 \\
\hline Soybean meal & 33.39 & 33.19 & 33.17 \\
\hline Corn gluten meal & 2.25 & 2.25 & 2.25 \\
\hline Wheat bran & 5.46 & 6.70 & 6.80 \\
\hline Soybean oil & - & - & 1.30 \\
\hline Tallow & 1.30 & - & - \\
\hline Palm kenel oil & - & 1.30 & - \\
\hline Tricalcium phosphate & 1.35 & 1.35 & 1.35 \\
\hline Limestone & 1.14 & 1.14 & 1.14 \\
\hline Salt & 0.36 & 0.36 & 0.36 \\
\hline DL-Methionine (98\%) & 0.10 & 0.10 & 0.10 \\
\hline Mineral $\operatorname{mix}^{2}$ & 0.10 & 0.10 & 0.10 \\
\hline Vitamin $\operatorname{mix}^{3}$ & 0.10 & 0.10 & 0.10 \\
\hline Total & 100.00 & 100.00 & 100.00 \\
\hline \multicolumn{4}{|l|}{ Chemical composition } \\
\hline ME (kcal/kg) & 3,200 & 3,200 & 3,200 \\
\hline Crude protein $(\%)$ & 21.50 & 21.50 & 21.50 \\
\hline Ether extract $(\%)$ & 3.96 & 3.98 & 3.98 \\
\hline Crude fibre (\%) & 3.19 & 3.27 & 3.27 \\
\hline Ash (\%) & 6.06 & 6.10 & 6.10 \\
\hline $\mathrm{Ca}(\%)$ & 1.00 & 1.00 & 1.00 \\
\hline Available P (\%) & 0.45 & 0.45 & 0.45 \\
\hline Lysine (\%) & 1.15 & 1.15 & 1.15 \\
\hline Methionine (\%) & 0.43 & 0.43 & 0.43 \\
\hline \multicolumn{4}{|c|}{$\begin{array}{l}{ }^{1} \text { Starter diet provided during d } 1 \text { to } 21 \text {; Finisher diet provided during } \\
\text { d } 22 \text { to } 35 \text {. }\end{array}$} \\
\hline \multicolumn{4}{|c|}{$\begin{array}{l}{ }^{2} \text { Provided per kg of complete diet: } 37.5 \mathrm{mg} \mathrm{Zn}\left(\text { as } \mathrm{ZnSO}_{4}\right) ; 37.5 \\
\mathrm{mg} \mathrm{Mn}\left(\text { as } \mathrm{MnO}_{2}\right) ; 37.5 \mathrm{mg} \mathrm{Fe}\left(\text { as } \mathrm{FeSO}_{4} \cdot 7 \mathrm{H}_{2} \mathrm{O}\right) ; 3.75 \mathrm{mg} \mathrm{Cu} \\
\left.\left.\text { (as } \mathrm{CuSO}_{4} \cdot 5 \mathrm{H}_{2} \mathrm{O}\right) ; 0.83 \mathrm{mg} \mathrm{I} \text { (as } \mathrm{KI}\right) \text {; and } 0.23 \mathrm{mg} \mathrm{Se} \text { (as } \\
\left.\mathrm{Na}_{2} \mathrm{SeO}_{3} \cdot 5 \mathrm{H}_{2} \mathrm{O}\right) \text {. }\end{array}$} \\
\hline \multicolumn{4}{|c|}{$\begin{array}{l}{ }^{3} \text { Provided per } \mathrm{kg} \text { of complete diet: } 15,000 \mathrm{IU} \text { of vitamin } \mathrm{A}, 3,750 \\
\mathrm{IU} \text { of vitamin } \mathrm{D}_{3}, 37.5 \mathrm{IU} \text { of vitamin } \mathrm{E}, 2.55 \mathrm{mg} \text { of vitamin } \mathrm{K}_{3} \text {, } \\
3 \mathrm{mg} \text { of thiamin, } 7.5 \mathrm{mg} \text { of rivoflavin, } 4.5 \mathrm{mg} \text { of vitamin } \mathrm{B}_{6} \text {, } \\
24 \mathrm{ug} \text { of vitamin } \mathrm{B}_{12}, 51 \mathrm{mg} \text { of niacin, } 1.5 \mathrm{mg} \text { of folic acid, } 0.2 \\
\mathrm{mg} \text { of biotin and } 13.5 \mathrm{mg} \text { of Ca-pantothenate. }\end{array}$} \\
\hline
\end{tabular}

On day 0, 7, 21 and 35 broilers were weighed, and feed intake was calculated to determine average BWG, FI, and FCR.

To find out the nutrient digestibility of dry matter and nitrogen on days $28 \%$ to $35 \%, 0.2 \%$ of chromic oxide as an indigestible marker was added to the diets. Fresh excreta samples were collected from each pen on days 33, 34, and 35 and stored at $-20^{\circ} \mathrm{C}$ until analyzed. Before starting chemical analysis, the excreta samples were thawed and dried at $70^{\circ} \mathrm{C}$ for $72 \mathrm{~h}$. Soon after, dried samples were grinded well and passed through a $1 \mathrm{~mm}$ screen. All feed and fecal samples were freeze-dried and finely ground to pass through a $1 \mathrm{~mm}$ screen. $\mathrm{DM}$ and $\mathrm{N}$ digestibility were determined using methods established by the Association of Official Analytical Chemists (AOAC, 2000). UV absorption spectrophotometry (UV- 1201, Shimadzu, Kyoto, Japan was used to determine chromium in the diets and feces and Parr 6100 oxygen bomb calorimeter (Parr Instrument Co., Moline, IL, USA) was used to analyze energy by measuring the heat of combustion in the samplesThe apparent total tract digestibility of nutrients was calculated by the following techniques digestibility $(\%)=\{1-[(\mathrm{Nf} \times \mathrm{Cd})$ / $(\mathrm{Nd} \times \mathrm{Cf})]\} \times 100$, where Nf: nutrient concentration in feces (\% DM), Cd: chromium concentration in diet (\% DM), Nd: nutrient concentration in diet $(\% \mathrm{DM})$, and $\mathrm{Cf}$ : chromium concentration in feces (\% DM).

All data were analyzed using the GLM procedure of SAS/ STAT $^{\circledR}$ (Statistical Analysis System, version 9.2, Cary, NC, USA). Replication ( $n=13$ ) was used as the experimental unit. Orthogonal contrasts were used for the effects of treatments. Mean values and standard errors of the mean were reported. A threshold value of $P<0.05$ was established to denote statistical significance and $P<0.1$ was considered a trend.

\section{RESULTS AND DISCUSSION}

Earlier studies indicated that supplementation of vegetable oils such as palm oil and soybean oil in broiler diet had positive impact on the growth performance (Blanch et al., 1996; Zhao and Kim, 2017), which agrees with our study. The supplementation of palm oil and soy oil in broilers fed has trended to increase $(P=0.089)$ body weight gain at day 7 to 21 . While, body weight gain was significantly improved $(P<0.05)$ during 
overall experiment period compared than the control diet. In addition, the palm oil treatment group has significantly improved the body weight gain compared to the soy oil treatment group $(P<0.05)$. In contrast, Ao and Kim (2020) stated that soy oil supplementation had enhance the body weight gain in pekin ducks comparability to palm oil treatment group. The contradictory was happening in this result due to the variation of animals and differences in palm oil and soy oil dietary compositions. However, in the overall experiment feed intake (FI) was trend to increase in palm oil treatment group compared to other groups. There was no significant effect on FCR during overall trial (Table 3) our findings concede with the of Azman et al. (2004) and Abdulla et al. (2016) who stated that the supplementation of dietary soy oil did not affect the FI in broilers. The inclusion of soybean oil had improved body weight gain and reduced FCR compared with tallow in chicken indicated by Zhang et al. (2011). In addition, Febel et al. (2008) and De Witt et al. (2009) reported that dietary inclusion with soy oil had no beneficial effect on the FI and FCR of chicken.

In previous study, Zhang et al. (2011) denote that the inclusion of soy oil and palm oil in broiler fed had no significant effect on nutrient digestibility of $\mathrm{DM}, \mathrm{N}$, and energy. Similarly, our findings also have no significant $(P>0.05)$ effect on nutrient digestibility of dry matter (DM), nitrogen $(\mathrm{N})$, and energy due to the dietary soy oil and palm oil supplementation showed in Table 4. Moreover, Kavouridou et al. (2008), reported that nutrient digestibility of nitrogen had not significantly affect the broilers fed diet containing palm oil, soybean oil and linseed oil. In contrast, Chung et al. (1993)

Table 3. The effect of palm oil and soy oil supplementation on growth performance in broilers ${ }^{1}$

\begin{tabular}{|c|c|c|c|c|c|c|}
\hline \multirow{2}{*}{ Items } & \multirow{2}{*}{$\mathrm{CON}$} & \multirow{2}{*}{$\mathrm{T} 1$} & \multirow{2}{*}{$\mathrm{T} 2$} & \multirow{2}{*}{$\mathrm{SEM}^{2}$} & \multicolumn{2}{|c|}{$P$-value } \\
\hline & & & & & Con vs. others & T1 vs. $\mathrm{T} 2$ \\
\hline \multicolumn{7}{|l|}{ d 1 to 7} \\
\hline BWG (g) & 104 & 109 & 105 & 2.62 & 0.428 & 0.351 \\
\hline FI (g) & 126 & 130 & 125 & 3.85 & 0.719 & 0.388 \\
\hline FCR & 1.204 & 1.197 & 1.195 & 0.030 & 0.961 & 0.677 \\
\hline \multicolumn{7}{|l|}{ d 7 to 21} \\
\hline BWG (g) & 614 & 635 & 623 & 7.18 & 0.089 & 0.266 \\
\hline FI (g) & 1,053 & 1,073 & 1,062 & 7.09 & 0.147 & 0.349 \\
\hline FCR & 1.718 & 1.692 & 1.707 & 0.025 & 0.335 & 0.674 \\
\hline \multicolumn{7}{|l|}{ d 21 to 35} \\
\hline BWG (g) & 950 & 991 & 962 & 13.54 & 0.112 & 0.143 \\
\hline FI (g) & 1,767 & 1,804 & 1,763 & 20.15 & 0.495 & 0.156 \\
\hline FCR & 1.863 & 1.822 & 1.835 & 0.027 & 0.372 & 1.00 \\
\hline \multicolumn{7}{|l|}{ Overall } \\
\hline BWG (g) & $1,667^{\mathrm{b}}$ & $1,735^{\mathrm{a}}$ & $1,691^{\mathrm{ab}}$ & 14.52 & 0.017 & 0.042 \\
\hline FI (g) & 2,945 & 3,007 & 2,950 & 22.37 & 0.236 & 0.083 \\
\hline FCR & 1.767 & 1.733 & 1.745 & 0.017 & 0.380 & 0.759 \\
\hline
\end{tabular}

${ }^{1}$ Abbreviation: CON, basal diet; $\mathrm{T} 1$, basal diet $+1.3 \%$ palm oil; $\mathrm{T} 2$, basal diet $+1.3 \%$ soy oil.

${ }^{2}$ Standard error of means. Values are represented by 13 replicates/treatment, 18 chickens/cage into three treatment groups.

a,b Mean values within a row without a common superscript differ significantly $(P<0.05)$.

BWG, body weight gain; FI, feed intake; FCR, feed conversion ratio. 
Table 4. The effect of palm oil and soy oil supplementation on nutrient digestibility in broilers ${ }^{1}$

\begin{tabular}{|c|c|c|c|c|c|c|}
\hline \multirow{2}{*}{ Items $(\%)$} & \multirow{2}{*}{$\mathrm{CON}$} & \multirow{2}{*}{$\mathrm{T} 1$} & \multirow{2}{*}{$\mathrm{T} 2$} & \multirow{2}{*}{$\mathrm{SEM}^{2}$} & \multicolumn{2}{|c|}{$P$-value } \\
\hline & & & & & Con vs. others & $\mathrm{T} 1$ vs. $\mathrm{T} 2$ \\
\hline Dry matter & 70.62 & 71.39 & 70.89 & 0.810 & 0.607 & 0.666 \\
\hline Nitrogen & 68.6 & 69.66 & 69.21 & 0.817 & 0.417 & 0.702 \\
\hline Energy & 69.05 & 69.72 & 69.23 & 0.976 & 0.728 & 0.731 \\
\hline
\end{tabular}

${ }^{1}$ Abbreviation: CON, basal diet; $\mathrm{T} 1$, basal diet $+1.3 \%$ palm oil; $\mathrm{T} 2$, basal diet $+1.3 \%$ soy oil.

${ }^{2}$ Standard error of means. Values are represented by 13 replicates/treatment, 18 chickens/cage into three treatment groups.

and Zollitsch et al. (1997) believed that vegetable oil is rich in unsaturated fatty acids that helps animals for easy digestion than animal fat which is rich in saturated fatty acids. However, the lack of nutrient digestibility performance among species and the usage of palm oil and soy oil composition in the diet was limited. we could not conclude our studies related to this diet supplementation. Thus, further investigation is needed to determine the nutrient digestibility of broilers fed with palm oil and soy oil.

\section{SUMMARY}

The present study will be the base of forthcoming research. The dietary supplementation of palm oil and soy oil has a positive effect on broilers growth performance. However, in this study palm or soy oil additive has not affect the nutrient digestibility. Therefore, more investigation and wide knowledge is needed to understand overall functional performance in broilers with different percentage of palm oil and soy oil supplementation.

\section{ORCID}

Vetriselvi Sampath https://orcid.org/0000-0002-6726-8568 Jae Hong Park https://orcid.org/0000-0002-2025-0141

In Ho Kim https://orcid.org/0000-0001-6652-2504

\section{REFERENCES}

Abdulla NR, Loh TC, Akit H, Sazili AQ, Foo HL 2016 Effect of dietary oil sources and calcium: phosphorus levels on growth performance, gut morphology and apparent digestibility of broiler chickens. S Afr J Anim Sci 46:42-53.

Ao X, Kim IH 2020 Effects of dietary lipid sources on growth performance and carcass traits in Pekin ducks. Poult Sci 9:499-504.

AOAC 2000 Official Methods of Analysis. 18th. ed. Rev. 2. Association of Official Analytical Chemists International, Gaithersburg MD.

Ayed HB, Attia H, Ennouri M 2015 Effect of oil supplemented diet on growth performance and meat quality of broiler chickens. Adva Techni Biol Medi 4:1-4.

Ayisi CL, Zhao J, Rupia EJ 2017 Growth performance, feed utilization, body and fatty acid composition of Nile tilapia (Oreochromis niloticus) fed diets containing elevated levels of palm oil. Aquacult Fish 2:67-77.

Azman M, Konar V, Seven P 2004 Effects of different dietary fat sources on growth performances and carcass fatty acid composition of broiler chickens. Revue de Méd Vét 155:278-286.

Babalola TO, Apata DF, Omotosho JS, Adebayo MA 2011 Differential effects of dietary lipids on growth performance, digestibility, fatty acid composition and histology of African catfish (Heterobranchus longifilis) fingerlings. Food Nutr Sci 2:11-21.

Bae KH, Ko TG, Kim JH, Cho WT, Han YK, Han IK 1999 Use of metabolically active substances to substitute for antibiotics in finishing pigs. Korean J Anim Sci 41: 23-30.

Blanch A, Barroeta AC, Baucells MD, Serrano X, Puchal F 1996 Utilization of different fats and oils by adult chickens as a source of energy, lipid and fatty acids. Anim Feed Sci Technol 61:335-342.

Chung HC, Guenter W, Rotter RG, Crow GH, Stanger NE 1993 
Effects of dietary fat source on sudden death syndrome and cardiac sarcoplasmic reticular calcium transport in broiler chickens. Poult Sci 72:310-316.

De Sousa Lima VB, Dourado LRB, Machado LP, Biagiotti D, de Lima SBP 2016 Cottonseed oil in diets for broilers in the pre-starter and starter phases. PloS One 11:e0147695.

De Witt F, Els S, Van der Merwe H, Hugo A, Fair M 2009 Effect of dietary lipid sources on production performance of broilers. S Afr J Anim Sci 39:45-48.

Fébel H, Mezes M, Palfy T, Herman A, Gundel J, Lugasi A, Balogh K, Kocsis I, Blazovics A 2008 Effect of dietary fatty acid pattern on growth, body fat composition and antioxidant parameters in broilers. J Anim Physiol 92:369-376.

Huang Y, Yoo JS, Kim HJ, Wang Y, Chen YJ, Cho JH, Kim IH 2010 Effects of dietary supplementation with blended essential oils on growth performance, nutrient digestibility, blood profiles and fecal characteristics in weanling pigs. Asian Austral J Anim Sci 23:607-613.

Kamran J, Mehmood S, Mahmud A, Saima 2020 Effect of fat sources and emulsifier levels in broiler diets on performance, nutrient digestibility, and carcass parameters. Braz. J Poult Sci 22:001-010.

Kavouridou K, Barroeta A, Villaverde C, Manzanilla E, Baucells M 2008 Fatty acid, protein and energy gain of broilers fed different dietary vegetable oils. Span J Agri Res 6:210-218.

Murugesan GR, Kerr BJ, Persia ME 2013 Evaluation of energy values of various oil sources when fed to broiler chicks. Anim Ind Rep 659:14-815.

NRC 1994 Nutrient Requirements of Poultry. 9th rev. ed. National Academic Press, Washington, DC.
Saleh EA, Watkins SE, Waldroup AL, Waldroup PW 2004 Effects of dietary nutrient density on performance and carcass quality of male broilers grown for further processing. Int Poult Sci 3:1-10.

Shingfield KJ, Lee MRF, Humphries DJ, Scollan ND, Toivonen V, Beever DE, Reynolds CK 2011 Effect of linseed oil and fish oil alone or as an equal mixture on ruminal fatty acid metabolism in growing steers fed maize silage-based diets. J Anim Sci 89:3728-3741.

Smink W, Gerrits WJJ, Hovenier R, Geelen MJH, Lobee HJW, Verstegen MWA, Beynen AC 2008 Fatty acid digestion and deposition in broiler chickens fed diets containing either native or randomized palm oil. Polut Sci 87:506-513.

Wilson KJ, Bayer RS 2000 Poultry Nutrition Information for the Small Flock. Kansas State University.

Zhang BK, Li HT, Zhao DQ, Guo YM, Barri A 2011 Effect of fat type and lysophosphatidylcholine addition to broiler diets on performance, apparent digestibility of fatty acids, and apparent metabolizable energy content. Anim Feed Sci Technol 163:177-184.

Zhao PY, Kim IH 2017 Effect of diets with different energy and lysophospho lipids levels on performance, nutrient metabolism, and body composition in broilers. Poult Sci 96:1341-1347.

Zollitsch W, Knaus W, Aichinger F, Lettner F 1997 Effects of different dietary fat sources on performance and carcass characteristics of broilers. Anim Feed Sci Technol 66:63-73.

Received Jun. 19, 2020, Revised Aug. 26, 2020, Accepted Aug. 26, 2020 